\title{
Prevalence of low back pain in different educational levels: a systematic review
}

\author{
Prevalência de dor lombar em diferentes níveis \\ educacionais: uma revisão sistemática
}

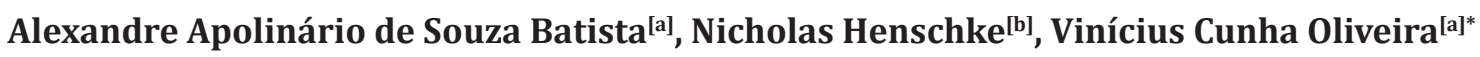

[a] Universidade Federal de Minas Gerais (UFMG), Belo Horizonte, MG, Brazil

[b] Institute of Public Health of Heidelberg (HIPH), Heidelberg, Germany

\begin{abstract}
Introduction: Non-specific low back pain (LBP) can be understood through the interaction of biopsychosocial factors such as education. Unfortunately, it remains unclear whether education can be considered an important risk and prognostic factor for the occurrence of LBP. Objective: To investigate the association between education and LBP. Methods: The following databases were searched: MEDLINE, EMBASE, Cochrane, AMED and PsyINFO. Results: Thirteen studies were included in the review. The Prevalence Critical Appraisal Instrument (PCAI) was used to assess risk of bias. Methodological quality scores ranged from 7 to 10 on a scale of $0-10$. There was a $23 \%$ (95\% CI, 13-37) prevalence of LBP (10,582 out of a total of 99,457 cases) in the general sample at the time of assessment. The meta-analysis of studies on the prevalence of LBP in people with low, medium or high educational level found the following results, respectively: 24\% (95\% CI, 12-43), $27 \%$ (95\% CI, 9-56), and 18\% (95\% CI, 5-50). The meta-regression identified heterogeneity among the studies included in the review. This can be explained by educational differences $(\mathrm{p}<0.05)$. Conclusion: Occurrence of LBP varies according to educational level. Individuals with higher educational levels are less often affected by LBP than individuals with medium or low educational levels.
\end{abstract}

Keywords: Low Back Pain. Prevalence. Education.

\footnotetext{
AASB: BS, e-mail: batista.fisioterapia@gmail.com NH: PhD, e-mail: nhenschke@gmail.com

VCO: PhD, e-mail: viniciuscunhaoliveira@yahoo.com.br
} 
Resumo

Introdução: A dor lombar inespecífica (DL) pode ser compreendida através da interação de fatores biopsicossociais, como por exemplo a educação. Infelizmente, ainda não é sabido se a educação é uma característica social importante como fator de risco e prognóstico para a ocorrência de DL. Objetivo: Investigar a associação entre educação e ocorrência de DL. Métodos: Buscas em MEDLINE, EMBASE, Cochrane, AMED e PsyINFO. Resultados: Incluídos 13 estudos na revisão. Para o risco de viés foi utilizado a Prevalence Critical Appraisal Instrument (PCAI) obtendo na avaliação da qualidade metodológica os escores menor e maior de 7 e 10 em uma escala de 0 a 10. Amostra geral compreendeu prevalência de DL no momento da avaliação de 23\% (IC95\% 13 até 37), sendo 10582 o número de casos em 99457. Meta-analysis com estudos investigando prevalência de DL no momento da avaliação em pessoas de baixo, médio e alto nível educacional estimou respectivamente os valores 24\% (IC95\% 12 até 43), 27\% (IC95\% 9 até 56), e 18\% (IC95\% 5 até 50). Meta-regressão identificou heterogeneidade entre os estudos incluídos e essa pode ser explicada pelo nível educacional $(p<0,05)$. Conclusão: Ocorrência de DL varia de acordo com o nível educacional, onde indivíduos com nível educacional mais alto possuem menor ocorrência de DL quando comparados com indivíduos com nível educacional baixo ou médio.

Palavras-chave: Dor Lombar. Prevalência. Educação.

\section{Introduction}

Spinal problems are one of the most common reasons for clinical visits and the leading cause of disability in the adult population [1]. Non-specific low back pain (LBP) affects approximately 70$80 \%$ of workers in industrialized cities at some point in life, leading to cases of retirement due to functional disability [2]. About 10 million Brazilians have disabilities due low back pain and $70 \%$ of the Brazilian population will experience pain episodes at some time in life [3]. Moreover, due to the high incidence and prevalence of disability in people of economically active age, LBP is considered a public health problem [3].

Our knowledge of risk factors and predisposition to LBP may benefit substantially from bibliographic searches $[1,4,5]$. LBP may be understood through the interaction of risk factors and biopsychosocial prognostic factors that are determined by physical (e.g., physical strength), psychological (e.g., kinesiophobia) and social aspects (e.g., social support) $[4,5]$. In this context, education is the best substitute to measure social status, because it is easy to collect information on it and it is not likely to be affected by chronic diseases [6]. This provides a rapid and useful strategy for a more complex understanding of the set of social factors that predispose the occurrence of LBP [6-13]. Education is one of the social factors often studied in relation to LBP [6-15].

Despite the fact that primary observation and sample characterization are present in several studies, it remains unclear whether education is an important social characteristic to be used as a risk and prognostic factor for the occurrence of LBP. Thus, systematic reviews may make it possible to identify findings that elucidate the impact of formal education as a risk and prognostic factor for LBP. Moreover, we believe that these findings may suggest procedures for individual and collective physical therapy treatment of this morbidity. Given the above, the aim of this study was to undertake a systematic review to investigate the association between educational level and the occurrence of LBP.

\section{Methods}

We searched the electronic databases MEDLINE (via OVID), EMBASE, Cochrane, AMED and PsyINFO. The searches were conducted between May 1 and 31,2015 . We used keywords related to "low back pain", "prevalence" and "education". There were no restrictions on language or publication date. All the studies included in the review met the following 
criteria: 1) to investigate the LBP of any duration, in patients of both sexes aged 18 years or over; and 2) to associate formal education with the presence or absence of LBP. Papers on conditions specific for the occurrence of LBP, such as fractures, tumors, infection, inflammation, cauda equina syndrome, radiculopathy and pregnancy (non-specific low back pain), were excluded.

\section{Studies selection process}

After removing duplicates and screening titles and abstracts, full-text versions of potential papers were selected. A reviewer (AASB) assessed the full versions of the texts according to the inclusion and exclusion criteria. Adjudication by a second reviewer ( $\mathrm{NH}$ ) resolved any ambiguity regarding study inclusion.

\section{Data extraction}

Two reviewers (AASB and NH) extracted data using a standardized form. Disagreements were resolved by consensus. Discrepancies were resolved as needed by a third investigator (VCO) who made the final decision. The data were extracted as follows: 1) study design; 2) population characteristics; 3 ) measures of formal education; and 5) measures of LBP prevalence by educational level.

\section{Risk of bias}

Studies were assessed for methodological quality by one reviewer (AASP) using the Prevalence Critical Appraisal Instrument (PCAI) [16]. The PCAI assesses studies for methodological quality based on 10 questions with four reply options ("yes", "no", "unclear" and "does not apply"). The questions refer to: 1 ) representativeness of the population; 2) sample selection; 3) sample size; 4) subjects' details; 5) sample conduction and identification; 6) objective, standard criteria used for the measurement of the condition; 7) reapplicability of the measure; 8 ) appropriate statistical method; 9) confounding factors, subgroups, etc.; and 10) subpopulations identified using objective criteria. A second reviewer $(\mathrm{NH})$ resolved any uncertainties in relation to the assessment through discussion and by consensus with the first reviewer.

Statistical Analysis

Due to differences in the classification of formal education used in the studies, this variable had to be reclassified to allow for synthesis of data. The reclassification was performed by two reviewers (AASB and VCO), who defined three categories (low, medium and high), based on the Brazilian education classification criteria. The number of years of formal education was classified as follows: 0 - 9 years as low educational level; 10 - 12 years as medium educational level; 13 or more years as high educational level [17]. This allowed a cutoff value to be defined for the studies and uncertainties were resolved by consensus between the authors.

LBP prevalence for each educational level was estimated and meta-analysis was conducted whenever possible. $I^{2}$ statistics [18] was used to determine the possibility of performing meta-analysis. Whenever $\mathrm{I}^{2}<50 \%$, meta-analysis was conducted using a fixed-effect model, whereas a random-effects model was used when $\mathrm{I}^{2} \geq 50 \%$. If even after using a random-effects model, $\mathrm{I}^{2} \geq 50 \%$, then the results were described qualitatively. Prevalence was presented as percentage, with 95\% confidence interval ( $95 \% \mathrm{CI})$. Meta-regression was carried out to test whether educational level could explain the heterogeneity found in LBP prevalence for all groups of educational levels. All the analyses were conducted using the Comprehensive Meta-analysis software, version 2.2.04 (Biostat, Inc. ${ }^{\odot}$, Englewood, New Jersey).

\section{Results}

\section{Studies selection process}

Figure 1 shows a flowchart of the studies process, as well as the total number of original studies included for review. 


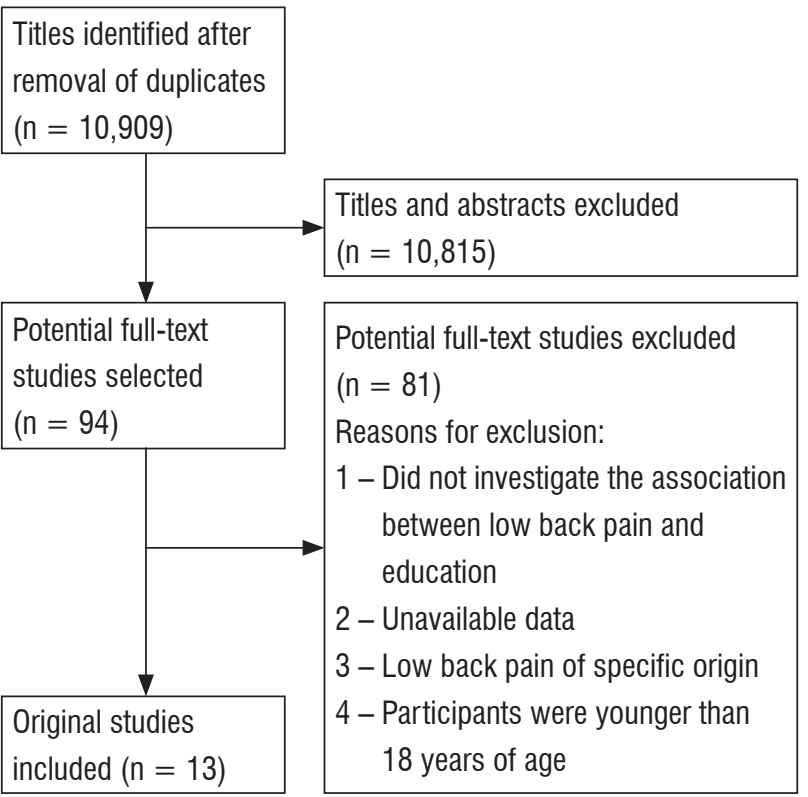

Figure 1 - Selection of studies for review.
Characteristics of the studies included

Thirteen studies from nine countries associated education with LBP and were included in the review. They all had a low risk of bias ( 7 or more out of 10 ). The studies with the smallest and the largest sample size included 34 [19] and 4,760 participants [20], respectively. Sixty-two percent of the studies included in the review were cross-sectional (Table 1). We found a predominance of people in the economically active age-group, i.e., aged 25-55 years [3, 19-24]. One study associated LBP with education in noninstitutionalized older adults [25] and three studies included older adults in their samples [21, 26, 27].

Two papers had been published in the USA [20, 21], two in Germany [26, 27], two in the Netherlands [23, 28] and two in Belgium [29, 30]. The review also included studies published in Japan, Hong Kong, Brazil, Sweden and South Korea.

Table 1 - Characteristics of the studies included $(n=13)$

\begin{tabular}{|c|c|c|c|c|}
\hline \multirow{4}{*}{$\begin{array}{l}\text { First author, } \\
\text { year, country } \\
\text { Nagi (1973) } \\
\text { USA }\end{array}$} & \multirow{4}{*}{$\begin{array}{l}\text { Study design } \\
\text { Cross-sectional }\end{array}$} & \multirow{4}{*}{$\begin{array}{l}\text { Subjects (n) } \\
\text { People aged 18-64 years living in a metropolitan city. }\end{array}$} & \multicolumn{2}{|c|}{$\begin{array}{l}\text { Prevalence of LBP according } \\
\text { to education level attained \% } \\
\text { ( } \mathrm{n} \text { of cases / total } n \text { ) }\end{array}$} \\
\hline & & & Low & $29.50 \%(36 / 122)$ \\
\hline & & & Medium & $44.25 \%(127 / 287)$ \\
\hline & & & High & $11.81 \%(39 / 330)$ \\
\hline $\begin{array}{l}\text { Lee (1989) } \\
\text { Hong Kong }\end{array}$ & Longitudinal & Patients from the University of Hong Kong, who had spinal pain & Low & $62.98 \%(34 / 54)$ \\
\hline \multirow{3}{*}{$\begin{array}{l}\text { Hurwitz } \\
\text { (1997) USA }\end{array}$} & \multirow{3}{*}{ Cross-sectional } & \multirow{3}{*}{ Non-institutionalized civil population aged 18 years or older. } & Low & $8.03 \%(621 / 7728)$ \\
\hline & & & Medium & $6.81 \%(726 / 10,659)$ \\
\hline & & & High & $5.30 \%(3,413 / 64,314)$ \\
\hline $\begin{array}{l}\text { Muramatsu } \\
\text { (1997) Japan }\end{array}$ & Cross-sectional & Non-institutionalized individuals aged 60 years or older. & Low & $17.99 \%(371 / 2062)$ \\
\hline \multirow{3}{*}{$\begin{array}{l}\text { Miedema } \\
\text { (1998) } \\
\text { Netherlands * }\end{array}$} & \multirow{3}{*}{ Longitudinal } & \multirow{3}{*}{$\begin{array}{l}\text { Dutchmen who sought medical care for musculoskeletal } \\
\text { disorders. }\end{array}$} & Low & $30.83 \%(70 / 227)$ \\
\hline & & & Medium & $28.65 \%(47 / 164)$ \\
\hline & & & High & $17.07 \%(7 / 41)$ \\
\hline \multirow{3}{*}{$\begin{array}{l}\text { Latza (2000) } \\
\text { Germany ** }\end{array}$} & \multirow{3}{*}{ Cross-sectional } & \multirow{3}{*}{ German population aged 25-74 years living in Lübeck } & Low & $50.63 \%(239 / 472)$ \\
\hline & & & Medium & $76.01 \%(168 / 221)$ \\
\hline & & & High & $79.31 \%(46 / 58)$ \\
\hline \multirow{2}{*}{$\begin{array}{l}\text { Goubert (2003) } \\
\text { Belgium *** }\end{array}$} & \multirow{2}{*}{ Cross-sectional } & \multirow{2}{*}{ Bicultural subjects in Belgium. } & Low & $44.32 \%(43 / 97)$ \\
\hline & & & High & $41.66 \%(632 / 1,517)$ \\
\hline \multirow{3}{*}{$\begin{array}{l}\text { Silva (2004) } \\
\text { Brazil }\end{array}$} & \multirow{3}{*}{ Cross-sectional } & \multirow{3}{*}{ Brazilians living in Southern Brazil. } & Low & $5.28 \%(103 / 1,949)$ \\
\hline & & & Medium & $2.81 \%(22 / 781)$ \\
\hline & & & High & $1.99 \%(9 / 452)$ \\
\hline \multirow{3}{*}{$\begin{array}{l}\text { Clays (2007) } \\
\text { Belgium }\end{array}$} & \multirow{3}{*}{ Longitudinal } & \multirow{3}{*}{$\begin{array}{l}\text { Public administration, private company and bank workers aged } \\
45 \text { years or older. }\end{array}$} & Low & $50.30 \%(488 / 970)$ \\
\hline & & & Medium & $42.55 \%(346 / 813)$ \\
\hline & & & High & $31.84 \%(236 / 741)$ \\
\hline
\end{tabular}


Table 1 - Characteristics of the studies included $(n=13)$

(Conclusion)

\begin{tabular}{|c|c|c|c|c|}
\hline \multirow[t]{2}{*}{$\begin{array}{l}\text { First author, } \\
\text { year, country }\end{array}$} & \multirow[t]{2}{*}{ Study design } & \multirow[t]{2}{*}{ Subjects (n) } & \multicolumn{2}{|c|}{$\begin{array}{l}\text { Prevalence of LBP according } \\
\text { to education level attained \% } \\
\text { ( } \mathrm{n} \text { of cases / total } \mathrm{n} \text { ) }\end{array}$} \\
\hline & & & Low & $38.89 \%(431 / 1,108)$ \\
\hline \multirow[t]{3}{*}{$\begin{array}{l}\text { Schneider (2007) } \\
\text { Germany **** }\end{array}$} & Longitudinal & Subjects fluent in German. & Medium & $\begin{array}{l}36.02 \% \\
(1,702 / 4,725)\end{array}$ \\
\hline & & & High & $28.00 \%(266 / 950)$ \\
\hline & & & Low & $33.91 \%(391 / 1,153)$ \\
\hline \multirow[t]{2}{*}{$\begin{array}{l}\text { Dijken (2008) } \\
\text { Sweden }\end{array}$} & Cross-sectional & Population aged 25-79 years recruited in Northern Sweden. & Medium & $\begin{array}{l}43.80 \% \\
(1,124 / 2,566)\end{array}$ \\
\hline & & & High & $41.64 \%(862 / 2,070)$ \\
\hline Oostrom (2011) & & & Low & $7.19 \%(212 / 2,948)$ \\
\hline \multirow{2}{*}{$\begin{array}{l}\text { Netherlands } \\
\star \star \star \star *\end{array}$} & Longitudinal & Adult Dutch population. & Medium & $3.86 \%(60 / 1,552)$ \\
\hline & & & High & $4.22 \%(51 / 1,206)$ \\
\hline $\begin{array}{l}\text { Shim (2014) } \\
\text { South Korea }\end{array}$ & Cross-sectional & Male South Koreans aged 19 years or older. & $\begin{array}{l}\text { Medium } \\
\text { Hiah }\end{array}$ & $\begin{array}{l}69.07 \% .(755 / 1093) \\
66.94 \%(879 / 1313)\end{array}$ \\
\hline
\end{tabular}

Methodologicalqualityofthestudiesincludedforreview

The reviewers used the PCAI to assess the methodological quality of the studies included in the review. The highest and the lowest scores obtained were 7 and 10, respectively. Three studies were scored as 7 , three were scored as 8 , three were scored as 9 and four were scored as 10. A detailed view of the scores on the PCAI, the study authors and the year of publication are shown in Table 2.

Table 2 - Methodological quality of the studies included $(n=13)$

\begin{tabular}{|c|c|c|c|c|c|c|c|c|c|c|c|}
\hline Item & 1 & 2 & 3 & 4 & 5 & 6 & 7 & 8 & 9 & 10 & $\begin{array}{c}\text { Total Score } \\
\text { (from } 0 \text { to } 10 \text { ) }\end{array}$ \\
\hline Nagi (1973) & $\mathrm{Y}$ & UC & $\mathrm{N}$ & $Y$ & $Y$ & $\mathrm{~N}$ & $Y$ & $\mathrm{Y}$ & $Y$ & $Y$ & 7 \\
\hline Lee (1989) & $\mathrm{N}$ & $Y$ & $\mathrm{~N}$ & Y & Y & Y & Y & $\mathrm{N}$ & $Y$ & Y & 7 \\
\hline Hurwitz (1997) & Y & $Y$ & Y & $\mathrm{N}$ & Y & Y & N & Y & $Y$ & Y & 8 \\
\hline Muramatsu (1997) & Y & $Y$ & Y & Y & Y & $\mathrm{N}$ & Y & Y & $Y$ & $\mathrm{~N}$ & 8 \\
\hline Miedema (1998) & Y & $Y$ & $\mathrm{~N}$ & Y & Y & Y & Y & $\mathrm{N}$ & Y & Y & 8 \\
\hline Latza (2000) & $\mathrm{Y}$ & $\mathrm{Y}$ & $\mathrm{Y}$ & $\mathrm{Y}$ & Y & $\mathrm{Y}$ & $\mathrm{N}$ & $\mathrm{Y}$ & $\mathrm{Y}$ & $\mathrm{Y}$ & 9 \\
\hline Goubert (2003) & Y & Y & Y & Y & Y & Y & Y & Y & $Y$ & Y & 10 \\
\hline Silva (2004) & Y & $Y$ & Y & Y & Y & Y & Y & Y & Y & Y & 10 \\
\hline Clays (2007) & Y & $\mathrm{Y}$ & UC & Y & Y & Y & Y & Y & Y & Y & 9 \\
\hline Schneider (2007) & $\mathrm{Y}$ & $\mathrm{Y}$ & $\mathrm{Y}$ & $\mathrm{Y}$ & $\mathrm{Y}$ & $\mathrm{N}$ & $\mathrm{Y}$ & $\mathrm{N}$ & $\mathrm{Y}$ & $\mathrm{N}$ & 7 \\
\hline Dijken (2008) & Y & $\mathrm{Y}$ & $\mathrm{Y}$ & Y & Y & Y & Y & Y & Y & $\mathrm{N}$ & 9 \\
\hline Oostrom (2011) & Y & $\mathrm{Y}$ & Y & Y & Y & Y & Y & Y & Y & Y & 10 \\
\hline Shim (2014) & Y & Y & Y & Y & Y & Y & Y & Y & Y & Y & 10 \\
\hline
\end{tabular}

Note: $Y=$ yes; $N=$ no; $U C=$ unclear.

Associationbetweeneducationallevelandprevalenceof low back pain at the time of assessment

Meta-analysis using a random-effects model and including all educational levels found a weighted prevalence of LBP at the time of assessment of $23 \%$ (95\% CI, 13-37), from 10,582 cases out of a total of 99,457 (Figure 2). A randomeffects model was used due to heterogeneity above $50 \%$. Whereas $99 \%$ heterogeneity was observed when using the fixed-effect model, $0 \%$ heterogeneity was found when using the randomeffects model. 


\begin{tabular}{|c|c|c|c|c|c|c|c|}
\hline Studies & Prevalence & Total & & & $95 \%$ & $\mathrm{Cl}$ & Weight \\
\hline Nagi (1973) L & 0.30 & $36 / 122$ & +1 & & 0.22 & 0.38 & 5.21 \\
\hline Lee (1989) L & 0.63 & $34 / 54$ & & - & 0.49 & 0.75 & 5.12 \\
\hline Hurwitz (1997) L & 0.08 & $621 / 7728$ & 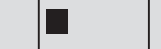 & & 0.07 & 0.09 & 5.31 \\
\hline Muramatsu (1997) L & 0.18 & 371 / 2062 & 口 & & 0.16 & 0.20 & 5.30 \\
\hline Silva (2004) L & 0.05 & $103 / 1949$ & 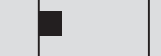 & & 0.04 & 0.06 & 5.28 \\
\hline Clays (2007) L & 0.50 & 488 / 970 & 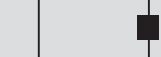 & 1 & 0.47 & 0.53 & 5.30 \\
\hline Dijken (2008) L & 0.34 & $391 / 1153$ & घ & & 0.31 & 0.37 & 5.30 \\
\hline Nagi (1973) M & 0.44 & 127 / 287 & - & & 0.39 & 0.50 & 5.28 \\
\hline Hurwitz (1997) M & 0.07 & $726 / 10659$ & $\square$ & & 0.06 & 0.07 & 5.31 \\
\hline Silva (2004) M & 0.03 & $22 / 781$ & & & 0.02 & 0.04 & 5.20 \\
\hline Clays (2007) M & 0.43 & $346 / 813$ & - & & 0.39 & 0.46 & 5.30 \\
\hline Dijken (2008) M & 0.44 & 1124 / 2566 & - & & 0.42 & 0.46 & 5.31 \\
\hline Shim (2014) M & 0.69 & 755 / 1093 & & घ & 0.66 & 0.72 & 5.30 \\
\hline Nagi (1973) H & 0.12 & $39 / 330$ & 口 & & 0.09 & 0.16 & 5.24 \\
\hline Hurwitz (1997) H & 0.05 & 3413 / 64314 & 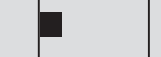 & & 0.05 & 0.05 & 5.31 \\
\hline Silva (2004) H & 0.02 & $9 / 452$ & 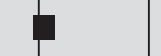 & & 0.01 & 0.04 & 5.04 \\
\hline Clays (2007) H & 0.32 & $236 / 741$ & [ & & 0.29 & 0.35 & 5.29 \\
\hline Dijken (2008) H & 0.42 & 862 / 2070 & - & & 0.40 & 0.44 & 5.31 \\
\hline Shim (2014) H & 0.67 & 879 / 1313 & & $\square$ & 0.64 & 0.69 & 5.30 \\
\hline \multirow[t]{2}{*}{ Pooling } & 0.23 & 10582 / 99457 & $>$ & & 0.13 & 0.37 & 100.00 \\
\hline & & & 0.00 & 1.00 & & & \\
\hline
\end{tabular}

Figure 2 - Meta-analysis of prevalence of low back pain at the time of assessment in all education groups.

Note: educational levels, $\mathrm{L}=$ low; $\mathrm{M}=$ medium; and $\mathrm{H}=$ high.

The meta-analysis of studies on the prevalence of LBP at the time of assessment in people with low educational level found a weighted prevalence of $24 \%$ (95\% CI, 12-43). Out of a total sample of 14,038 , there were 2,044 participants with low educational level. Meta-analysis found a weighted prevalence of
$27 \%$ (95\% CI, 9-56) of participants with medium educational level, i.e., 3,100 out of a total sample of 16,199 participants. Meta-analysis also found a weighted prevalence of $18 \%$ (95\% CI, 5-50) of participants with high educational level, i.e., 3,100 out of a total sample of 16199 participants (Figure 3).

\begin{tabular}{|c|c|c|c|c|c|}
\hline Studies & Prevalence & Total & $95 \%$ & $\mathrm{Cl}$ & Weight \\
\hline \multicolumn{6}{|c|}{ I) Meta-analysis of prevalence of LBP, by grouping studies that investigated low education levels } \\
\hline Nagi (1973) & 0.30 & $36 / 122$ & 0.22 & 0.38 & 14.07 \\
\hline Lee (1989) & 0.63 & $34 / 54$ & 0.49 & 0.75 & 13.66 \\
\hline Hurwitz (1997) & 0.08 & $621 / 7728$ & 0.07 & 0.09 & 14.48 \\
\hline Muramatsu (1997) & 0.18 & $371 / 2062$ & 0.16 & 0.20 & 14.47 \\
\hline Silva (2004) & 0.05 & $103 / 1949$ & 0.04 & 0.06 & 14.39 \\
\hline Clays (2007) & 0.50 & 488 / 970 & 0.47 & 0.53 & 14.46 \\
\hline Dijken (2008) & 0.34 & $391 / 1153$ & 0.31 & 0.37 & 14.46 \\
\hline Pooling & 0.24 & $2044 / 14038$ & 0.12 & 0.43 & 100.00 \\
\hline
\end{tabular}




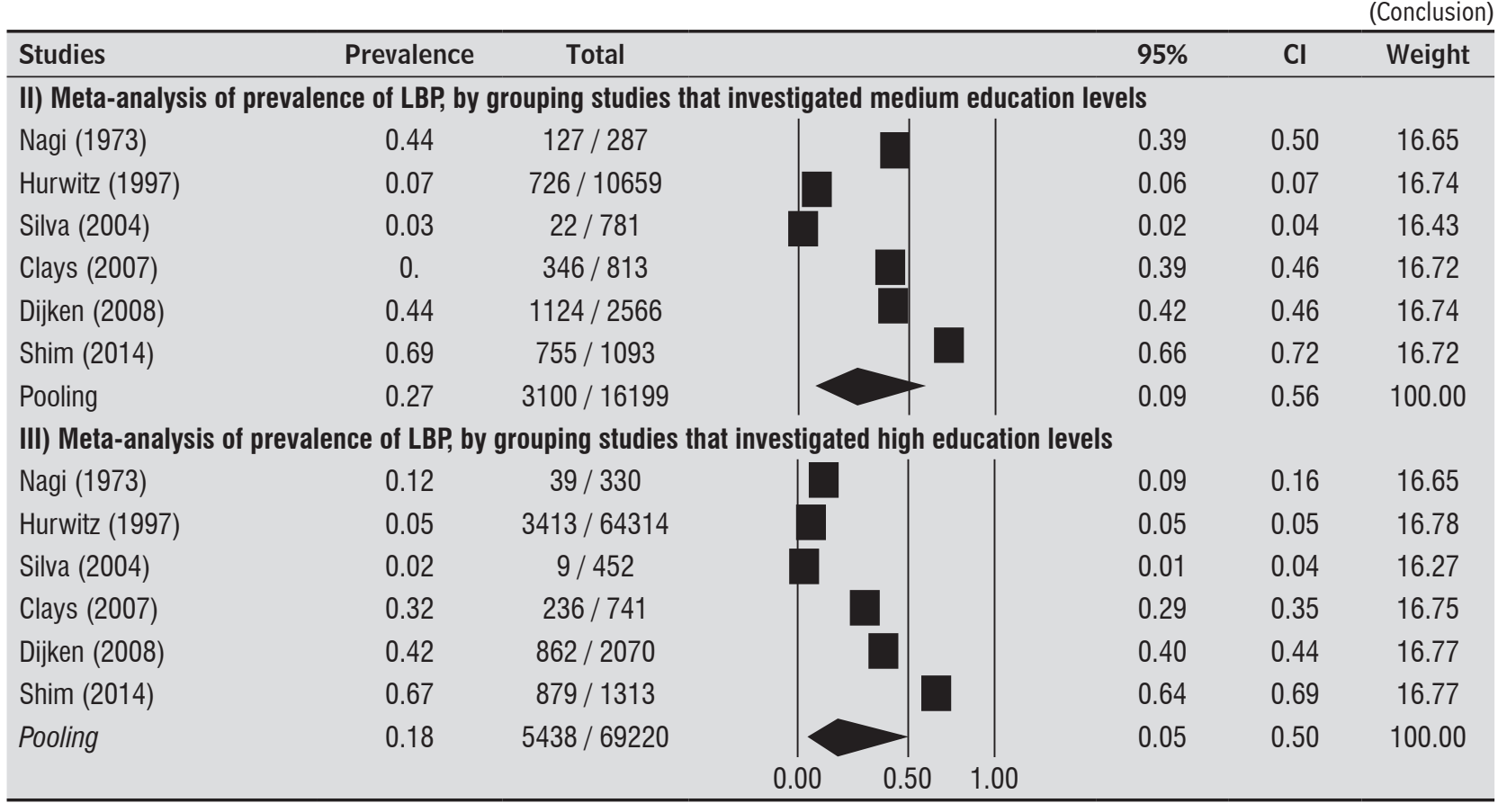

Figure 3 - Meta-analysis of prevalence of LBP at the time of assessment, according to educational level attained.

Associationbetweeneducationallevelandprevalenceof low back pain at other time points

Studies that did not investigate LBP at the time of assessment $[23,26,28-31]$ were not included in the meta-analysis. Qualitative analysis was conducted to investigate the prevalence of LBP at each time point studied and for each educational level. Two studies investigated the prevalence of LBP in the last twelve months $[28,31]$ in low, medium and high educational levels. The prevalence of low, medium and high educational levels, respectively, was: $30.8 \%, 28.7 \%$ and $17.1 \%$ [28]; and 38.9\%, 36.0\%, 28\% [31]. One study investigated the prevalence of LBP in the last six months [29] in high and low educational levels. The prevalence of low and high educational levels, respectively, were $44.3 \%$ and $41.7 \%$. One study investigated the prevalence of LBP in the last ten years in low, medium and high educational levels [23]. The prevalence of low, medium and high educational levels, respectively, was $7.2 \%, 3.9 \%$ and $4.2 \%$.

Meta-regressiontoinvestigatewhethereducationallevel impacts prevalence of low back pain

The use of meta-regression to investigate whether educational level could explain heterogeneity in LBP prevalence was only possible for studies that reported prevalence at the time of assessment. This is because only a small number of studies reported prevalence of LBP at other time points. The educational level attained explained the $99 \%$ heterogeneity found in the meta-analysis on LBP prevalence at the time of assessment in all educational levels grouped together $(\mathrm{p}<0.05)$.

\section{Discussion}

This systematic review aimed to investigate the association between educational level and the occurrence of LBP. Our findings suggest that, in a heterogenous sample for prevalence of LBP in all educational levels grouped together, people who attained higher educational levels show lower prevalence rates than people with low or medium educational levels.

These findings corroborate those of a systematic review by Dionne [15], demonstrating that individuals with less years of education are more susceptible to LBP and disability. They are also in line with the results found by Meucci [32], who found that, just like smoking and low economic status, low educational level is associated with an increased prevalence of LBP. In addition, when compared with previous 
reviews, the current review included newer studies and its meta-analysis on the prevalence of LBP in different educational levels was larger and more accurate. Moreover, meta-regression indicated that educational level is an important risk factor for the occurrence of LBP $(\mathrm{p}<0.05)$.

Our results suggest an important clinical implication. If educational level influences the occurrence of LBP, educational level may be an important psychosocial factor to be used in preventive and treatment approaches for LBP. Low and medium educational levels may be seen as risk and/or prognostic factors. Individual and group educational approaches should stress the importance of spine care and other factors that may influence the occurrence of LBP.

A cohort study by Mustard [33] found low educational level to be a risk factor for LBP (Odds Ratio: 1.8; 95\% CI, 1.2-2.7) and parental educational level to be a risk factor for LBP in children (Odds Ratio: 2.0; 95\% CI, 1.3 - 3.1). Thus, in addition to the individual consequences of LBP, parental educational level also seems to affect the occurrence LBP in children and adolescents.

It is possible that people's adherence to risky behaviors is greater in people with lower educational levels. One possible cause for the higher prevalence of LBP among people with medium and low educational levels could be that these people are exposed to different workloads and work activities than people with high educational levels [34-38].

Linton [39] analyzed psychological factors for the occurrence of LBP and reported that a confounding variable was the sample's educational level. Thus, education might not only be associated with the occurrence of LBP. If left unchecked, it could also produce information bias. Consequently, even in studies whose primary aim is not to investigate the prevalence of LBP, checking the education variable could possibly explain the results obtained. Thus, we found that educational level attained or number of years of education is a variable that is frequently used to characterize study samples, although this was not a primary aim in our searches. Studies with other aims have also described associations with education [40-48]. Studies assessing the prevalence of LBP reported associations with educational level, even though this was not their primary search goal [49-58]. Further studies having as their primary aim the investigation of the association of educational level attained or number of years of education with other variables are therefore needed to increase the number of studies eligible for meta-analysis that correlate education with the occurrence of LBP.

The small number of studies found for this review and the matching of these studies using the Brazilian education model may be one limitation of this review. We found 13 studies conducted in nine countries with different cultural, socioeconomic backgrounds. Because the formal education categories used in the studies included in this review were not consistent with each other, we had to recode the educational level variables based on Brazilian education classification criteria. This allowed the summary of the data. We suggest that future studies use years of formal education to facilitate the understanding of the role played by education in the occurrence of LBP. Possible limitations of this study include the lack of recording of the protocol used in the studies and the nonuse of the GRADE approach [59] to assess evidence quality, as suggested by PRISMA [60]. There were no limitations regarding the methodological quality of the studies included for review, as all the studies included had a score of 7 or more out of a maximum of 10 points on the scale.

\section{Conclusion}

Occurrence of LBP varies according to educational level. Individuals with higher educational levels are less often affected by LBP than individuals with medium or low educational levels.

\section{References}

1. Buchbinder R, Batterham R, Elsworth G, Dionne CE, Irvin E, Osborne RH. A validity-driven approach to the understanding of the personal and societal burden of low back pain: development of a conceptual and measurement model. Arthritis Res Ther. 2011;13(5):R152.

2. Deyo RA, Cherkin D, Conrad D, Volinn E. Cost, controversy, crisis: low back pain and the health of the public. Annu Rev Public Health. 1991;12:141-56. 
3. Silva MC, Fassa AG, Valle NCJ. Chronic low back pain in a Southern Brazilian adult population: prevalence and associated factors. Cad Saude Publica. 2004;20(2):377-85.

4. Skovron ML, Szpalski M, Nordin M, Melot C, Cukier D. Sociocultural factors and back pain: a populationbased study in Belgian adults. Spine (Phila Pa 1976). 1994;19(2):129-37.

5. Waddell G. The back pain revolution. London: Churchill Livingstone; 2004.

6. Heistaro S, Vartiainen E, Heliövaara M, Puska P. Trends of Back pain in eastern Finland, 1972-1992, in relation to socioeconomic status and behavioral risk factors. Am J Epidemiol. 1998;148(7):671-82.

7. Keefe FJ, Lumley M, Anderson T, Lynch T, Studts JL, Carson KL. Pain and emotion: new research directions. J Clin Psychol. 2001;57(4):587-607.

8. Callahan LF, Pincus T. Formal education level as a significant marker of clinical status in rheumatoid arthritis. Arthritis Rheum. 1988;31(11):1346-57.

9. Pincus T. Formal education level - A marker for the importance of behavioral variables in the pathogenesis, morbidity, and mortality of most diseases? J Rheumatol. 1988;15(10):1457-60.

10. Pincus T, Callahan LF. Formal education as a marker for increased mortality and morbidity in rheumatoid arthritis. J Chronic Dis. 1985;38(12):973-84.

11. Pincus T, Callahan LF. Taking mortality in rheumatoid arthritis seriously--predictive markers, socioeconomic status and comorbidity. J Rheumatol. 1986;13(5):841-5.

12. Pincus T, Callahan LF, Burkhauser RV. Most chronic diseases are reported more frequently by individuals with fewer than 12 years of formal education in the age 18-64 United States population. J Chronic Dis. 1987;40(9):865-74.

13. Syme SL, Berkman LF. Social class, susceptibility and sickness. Am J Epidemiol. 1976;104(1):1-8.

14. Blyth FM, Macfarlane GJ, Nicholas MK. The contribution of psychosocial factors to the development of chronic pain: the key to better outcomes for patients? Pain. 2007;129(1-2):8-11.
15. Dionne CE, Von Korff M, Koepsell TD, Deyo RA, Barlow WE, Checkoway H. Formal education and back pain: a review. J Epidemiol Community Health. 2001;55(7):455-68.

16. Munn Z, Moola S, Riitano D, Lisy K. The development of a critical appraisal tool for use in systematic reviews addressing questions of prevalence. Int J Health Policy Manag. 2014;3(3):123-8.

17. Brasil. Ministério da Educação. [cited 2015 Nov 17]. Available from: <http://portal.mec.gov.br/index. php>.

18. Higgins JPT, Green S, editors. Cochrane Handbook for Systematic Reviews of Interventions Version 5.1.0 [updated 2001 Mar]. The Cochrane Collaboration; 2011 [cited 2016 Feb 18]. Available from: https:// tinyurl.com/34pjxzu

19. Lee PW, Chow SP, Lieh-Mak F, Chan KC, Wong S. Psychosocial factores influencing outcome in patientes with low-back pain. Spine (Phila Pa 1976). 1989;14(8):838-43.

20. Hurwitz EL, Morgenstern H. Correlates of Back Problems and Back-Related Disability in the United States. J Clin Epidemiol. 1997;50(6):669-81.

21. Nagi SZ, Riley LE, Newby LG. A social epidemiology of back pain in a general population. J Chronic Dis. 1973;26(12):769-79.

22. Goubert L, Crombez G, De Bourdeaudhuij I. Low back pain, disability and back pain myths in a community sample: prevalence and interrelationships. Eur J Pain. 2004;8(4):385-94.

23. van Oostrom SH, Monique Verschuren WM, de Vet HC, Picavet HS. Ten year course of low back pain in an adult population-based cohort - the Doetinchem cohort study. Eur J Pain. 2011;15(9):993-8.

24. Shim JH, Lee KS, Yoon SY, Lee CH, Doh JW, Bae HG. Chronic low back pain in young Korean urban males: the life-time prevalence and its impact on health related quality of life. J Korean Neurosurg Soc. 2014;56(6):482-7.

25. Muramatsu N, Liang J, Sugisawa H. Transitions in chronic low back pain in Japanese older adults: a sociomedical perspective. J Gerontol B Psychol Sci Soc Sci. 1997;52(4):S222-34. 
26. Latza U, Kohlmann T, Deck R, Raspe H. Influence of occupational factors on the relation between socioeconomic status and self-reported back pain in a population-based sample of German adults with back pain. Spine (Phila Pa 1976). 2000;25(11):1390-7.

27. Björck-van Dijken C, Fjellman-Wiklund A, Hildingsson C. Low back pain, lifestyle factors and physical activity a population based study. J Rehabil Med. 2008;40(10):864-9.

28. Miedema HS, Chorus AM, Wevers CW, van der Linden S. Chronicity of back problems during working life. Spine (Phila Pa 1976). 1998;23(18):2021-8; discussion 2028-9.

29. Goubert L, Crombez G, De Bourdeaudhuij I. Low back pain, disability and back pain myths in a community sample: prevalence and interrelationships. Eur J Pain. 2004;8(4):385-94.

30. Clays E, De Bacquer D, Leynen F, Kornitzer M, Kittel F, De Backer G. The impact of psychosocial factors on low back pain longitudinal results from the Belstress study. Spine (Phila Pa 1976). 2007;32(2):262-8.

31. Schneider S, Mohnen SM, Schiltenwolf M, Rau C. Comorbidity of low back pain: representative outcomes of a national health study in the Federal Republic of Germany. Eur J Pain. 2007;11(4):387-97.

32. Meucci RD, Fassa AG, Faria NM. Prevalence of chronic low back pain: systematic review. Rev Saude Publica. 2015;49:1.

33. Mustard CA, Kalcevich C, Frank JW, Boyle M. Childhood and early adult predictors of risk of incident back pain: Ontario Child Health Study 2001 follow-up. Am J Epidemiol. 2005;162(8):779-86.

34. Griffith LE, Shannon HS, Wells RP, Walter SD, Cole DC, Côté $\mathrm{P}$, et al. Individual participant data meta-analysis of mechanical workplace risk factors and low back pain. Am J Public Health. 2012;102(2):309-18.

35. Kujala UM, Taimela S, Viljanen T, Jutila H, Viitasalo JT, Videman T, et al. Physical loading and performance as predictors of back pain in healthy adults. A 5-year prospective study. Eur J Appl Physiol Occup Physiol. 1996;73(5):452-8.
36. Latza U, Karmaus W, Stürmer T, Steiner M, Neth A, Rehder U. Cohort study of occupational risk factors of low back pain in construction workers. Occup Environ Med. 2000;57(1):28-34.

37. Bakker EW, Koning HJ, Verhagen AP, Koes BW. Interobserver reliability of the 24-hour schedule in patients with low back pain: a questionnaire measuring the daily use and loading of the spine. J Manipulative Physiol Ther. 2003;26(4):226-32.

38. Parato SMS, Fernandes RCP. Heavy physical work and low back pain: the reality in urban cleaning. Rev Bras Epidemiol. 2014;17(1):17-30.

39. Linton SJ. A review of psychological risk factors in back and neck pain. Spine (Phila $\mathrm{Pa}$ 1976). 2000;25(9):1148-56.

40. Lings S, Leboeuf YC. Whole-body vibration and low back pain: a systematic, critical review of the epidemiological literature 1992-1999. Int Arch Occup Environ Health. 2000;73(5):290-7.

41. Armenian HK, Halabi SS, Khlat M. Epidemiology of primary health problems in Beirut. J Epidemiol Community Health. 1989;43(4):315-8.

42. Croft PR, Rigby AS. Socioeconomic influences on back problems in the community in Britain. J Epidemiol Community Health. 1994;48(2):166-70.

43. Leigh JP, Sheetz RM. Prevalence of back pain among fulltime United States workers. Br J Ind Med. 1989;46(9):651-7.

44. Mäkelä M, Heliövaara M, Sievers K, Knekt P, Maatela J, Aromaa A. Musculoskeletal disorders as determinants of disability in Finns aged 30 years or more. J Clin Epidemiol. 1993;46(6):549-59.

45. Stronks K, van de Mheen $\mathrm{H}$, van den Bos J, Mackenbach JP. The interrelationship between income, health and employment status. Int J Epidemiol. 1997;26(3):592-600.

46. Tate DG. Workers' disability and return to work. Am J Phys Med Rehabil. 1992;71(2):92-6.

47. Volinn E, Van Koevering D, Loeser JD. Back sprain in industry. The role of socioeconomic factors in chronicity. Spine (Phila Pa 1976). 1991;16(5):542-8. 
48. Lancourt J, Kettelhut M. Predicting return to work for lower back pain patients receiving worker's compensation. Spine(Phila Pa 1976).1992;17(6):629-40.

49. Almeida ICGB, Sá KN, Silva M, Baptista A, Matos MA, Lessa I. Chronic low back pain prevalence in the population of the city of Salvador. Rev Bras Ortop. 2008;43(3):96-102.

50. Blay SL, Andreoli SB, Dewey ME, Gastal FL. Cooccurrence of chronic physical pain and psychiatric morbidity in a community sample of older people. Int J Geriatr Psychiatry. 2007;22(9):902-8.

51. Dellaroza MSG, Pimenta CAM, Duarte YA, Lebrão ML. Chronic pain among elderly residents in São Paulo, Brazil: prevalence, characteristics, and association with functional capacity and mobility (SABE Study). Cad Saude Publica. 2013;29(2):325-34.

52. Dotta TAG, Bonadio MB, Furlaneto ME, Silva JS, Leme LEG. Prevalence of acute diseases in the elderly assisted in emergency department of orthopedics. Acta Ortop Bras. 2014;22(2):99-101.

53. Lima MG, Barros MB, César CL, Goldbaum M, Carandina L, Ciconelli RM. Impact of chronic disease on quality of life among the elderly in the state of São Paulo, Brazil: a population-based study. Rev Panam Salud Publica. 2009;25(4):314-21.

54. Mascarenhas CHM, Silva Neto DG, Sampaio LS, Reis LA, Oliveira TS, Torres GV, et al. Prevalência e padrão de distribuição de patologias ortopédicas e neurológicas em idosos no hospital geral Prado Valadares. Rev Baiana Saude Publica. 2008;32(1):43-50.
55. Meneses SG. Correlação das alterações osteomioarticulares e dor em idosos de Morrinhos (CE). RBCEH. 2013;10(2):139-49.

56. Meucci RD, Fassa AG, Paniz VM, Silva MC, Wegman DH. Increase of chronic low back pain prevalence in a medium-sized city of southern Brazil. BMC Musculoskelet Disord. 2013;14:155.

57. Pereira LV, Vasconcelos PP, Souza LAF, Pereira GA, Nakatani AYK, Bachion MM. Prevalência, intensidade de dor crônica e autopercepção de saúde entre idosos: estudo de base populacional. Rev Lat Am Enfermagem. 2014;22(4):662-9.

58. Silva EF, Paniz VM, Laste G, Torres IL.. The prevalence of morbidity and symptoms among the elderly: a comparative study between rural and urban areas. Cien Saude Colet. 2013;18(4):1029-40.

59. GRADE Working Group. Grading quality of evidence and strength of recommendations. BMJ. 2014;328:1490.

60. Moher D, Liberati A, Tetzlaff J, Altman DG; PRISMA Group. Preferred reporting items for systematic reviews and meta-analyses: the PRISMA Statement. Ann Intern Med. 2009;151(4):264-9, W64.

Received on $05 / 05 / 2016$

Recebido em 05/05/2016

Approved on 04/10/2017

Aprovado em 10/04/2017 